\title{
RESTORING THE ETHICAL BASIS OF FINANCE
}

\author{
Abdul Karim Abdullah*
}

\begin{abstract}
Contemporary finance, both Islamic as well as conventional, is beset by challenges. These challenges have more in common than would appear at first sight. In Islamic finance, problems stem primarily from the tendency to replicate conventional instruments, while maintaining formal compliance with the Shariah. In conventional finance, it is becoming increasingly clear that the use of fixed income securities (borrowing at interest) is producing a range of unwelcome macroeconomic effects. These effects impose additional costs on society. They include indebtedness, reduced efficiency in the allocation of resources, inflation, unemployment, uneven distribution of wealth and instability in the form of business cycles. To the extent that Islamic finance replicates the instruments of conventional finance, it can be expected to replicate any adverse macroeconomic effects of debt financing as well. Thus, the response to the problems caused by interest-based finance, as well as its replication in Islamic finance, is to supplant financing by lending at interest with financing on the basis of risk sharing. In other words, it requires restoring finance to its ethical foundations. The transformation of finance from lending to risk sharing, however, will require not only a supportive transformation in social outlook, but also appropriate changes in the regulatory framework.
\end{abstract}

\section{Introduction}

The utilisation of interest-based financing is generally justified by pointing to the rapid development of the modern economies that widely utilise this form of financing. Lending at interest channelled vast sums of surplus capital (savings) into investment, by making loans at interest to business enterprises.

A closer look reveals, however, that financing growth by borrowing has facilitated economic development mainly in the short run, and only at the expense of significantly impairing it in the long term. It is becoming increasingly clear that development financed by lending at interest has imposed a range of burdens on society, of which debt is only the tip of the iceberg. Other adverse effects include unemployment, instability, inefficiency, uneven distribution of wealth and reduced economic growth. ${ }^{1}$

Overcoming these effects will require nothing less than transforming the entire monetary system to operate on the basis of risk sharing rather than interest-based lending. In other words, it will require restoring finance to its ethical basis. This will require amending the regulatory framework accordingly. It will also require a change in the moral outlook of society.

Lending at interest was first legalised in the English-speaking world in 1545 by Henry VIII. ${ }^{2}$ Religious strictures against usury were being relaxed in other 
European nations. ${ }^{3}$ Lending at interest was increasingly financing trade ${ }^{4}$ or, in the case of kings, waging wars. ${ }^{5}$ Columbus' discovery of the Americas in 1492 held out the prospect of an unprecedented amount of wealth flowing into Europe. The mercantile era (1500 to 1700 C.E.) was in full swing. At the same time, a transition from a feudal, agrarian society to an urban society was taking place.

One way to gain additional wealth - without work and taking risk - was to lend money at interest. Feudalism was taking on a new form. Instead of renting land to landless peasants, the nouveau riche - newly wealthy parties - were beginning to "rent" money itself. As a result of their inability to repay debts with interest, however, many indebted traders in the early seventeenth century UK went bankrupt. Their lands, used as collateral for loans, passed into the possession of lenders. In this way, lending at interest directly contributed to a growing gap between rich and poor, and to an increase in poverty.

By legalising usury Henry VIII broke with more than a thousand years of tradition. ${ }^{6}$ Making the practice of usury lawful changed the perception of what constitutes an acceptable way of earning a living, and also how people would relate to each other. The legalisation of usury signalled the acceptance of a practice that was for a long time considered a major sin by all major faiths, as well as a deeply unethical practice by non-religious observers. ${ }^{7}$ It helped to bring into being a wholly new, characteristically modern, society.

The new law allowed parties with surplus funds to earn income passively without work ('amal). In the case of secured loans, it allowed lenders to gain interest income even without sharing the risks of business enterprise. ${ }^{8}$ The legalisation of usury thus had the effect of undermining "work ethic," rather than the reverse, at least as far as lenders were concerned. ${ }^{9}$ The impact on debtors, by contrast, was predictably the reverse. Going into debt obliges debtors to work harder than before, and harder than would have been the case if they had remained, or been able to remain, debt-free.

The legalisation of lending at interest transformed what used to be a vice, if not into a virtue, at least into an ethically acceptable practice. In this way, it signified a moral transformation on a major scale. ${ }^{10}$ The full extent of the long-term effects of lending at interest, however, would not manifest itself until centuries later, in the current debt crisis ravaging a number of European countries, and threatening even Japan and the United States. These effects - the legacy of changes that took place several centuries ago - are currently manifesting themselves in the indebtedness of many nations, businesses and individuals. The public debt of Japan is currently at 230 per cent of GDP. The national debt of the US is in excess of 100per cent of GDP.

High and unsustainable burdens of debt now threaten entire nations with poverty. The prospect of social disintegration presented by the progressive 
polarisation of society into the wealthy few and the impoverished many, caused by the relentless operation of the interest mechanism as a means of wealth transfer, poses a threat to the social stability of all nations that rely extensively on the use of interest-based financing.

\section{Hidden costs of debt financing}

In order to overcome these problems and prevent a financial collapse, it is necessary to restructure the system of incentives so as to ensure that financing activities are carried out in ways that are consistent with the requirements of ethics. Practices that permit wealthy parties to gain additional wealth merely by lending money at interest, and for which no meaningful counter value (iwad) needs to be given up, in particular need to be discontinued.

A range of benefits can be expected from restructuring the financial system to operate on the basis of risk sharing rather than interest-based lending. These include greater efficiency in the allocation of resources, lower inflation, higher levels of employment, better growth, a more equitable distribution of wealth, and an enhanced systemic stability.

In the aftermath of the 2008 global financial crisis, questions about interestbased finance have arisen with a new sense of urgency. The need to service debt requires the diversion of funds from spending in the real sector to the repayment of debt. This reduces consumer spending, business investment and government expenditure on essential social services. ${ }^{11}$ Economic growth declines by the amount of money diverted, multiplied by the spending multiplier. In cases of debt owed by governments, repayment necessitates increases in taxes. Increases in taxes reduce disposable income, and with it the ability of people to spend in the real sector. ${ }^{12}$

The need to pay interest on debt is similar to the effects of taxes. ${ }^{13}$ The payment of interest on debt has the effect of concentrating wealth in fewer and fewer hands, and impoverishing growing numbers of ordinary persons at the same time. ${ }^{14}$ By channelling a disproportionate amount of wealth to lenders, interestbased lending leaves too few resources for meeting the needs of the poor. ${ }^{15} \mathrm{On}$ account of its sheer magnitude, lenders are unable to spend their interest income in the real sector at any rates comparable to those at which they acquire it. As a result, this income becomes concentrated in highly mobile, large pools of liquidity known as hedge funds. These funds are used mainly for the purpose of speculation rather than production, which results in mere wealth transfer rather than wealth creation.

Hedge funds are made up of "liquidity" that has been drained from the real sector by lending at interest and speculative activity. Such a concentration of liquidity outside of the real sector deprives the real economy of much needed 
investment funds, and produces a range of adverse effects besides. The more liquidity is drained from the real sector, the more economic activity slows down. Hedge funds make up the largely unregulated "shadow banking" sector. They operate in the borderless world of finance, largely unaccountable to anyone but their shareholders, mostly high net worth individuals. The funds scour the global financial landscape in search of new opportunities to maximise wealth for their shareholders. This takes place without much regard to the interests of the masses that may be adversely affected by such activities. Hedge funds - effectively hoarded funds - magnify the scope and effects of their activities through leverage. They borrow up to forty times their equity base. With a large amount of capital (leverage) at their disposal, they engage in predatory speculation on a large scale.

When asset bubbles caused by speculation inevitably burst, instability spreads by means of contagion far and wide. Those unable to liquidate their assets in time become the first victims. This was demonstrated by the recent subprime crisis, in which hedge funds were leading players, and indeed some of its early casualties. Hedge funds played a leading role in the Asian currency crisis of 1997, during which they destabilised a number of nations, and wiped out large amounts of wealth from their share and property markets. There is a need for stricter regulation of international finance. Hedge funds have turned international finance into a "Wild West" or a free for all of sorts. The international regulatory framework needs to be strengthened and given sweeping regulatory powers to bring the shadow banking system under control before any more damage to the economies of victim nations takes place.

One response is to tax credit transactions, and thereby promote investment in the real sector rather than speculation for a quick gain in the credit (bond) and derivatives (interest rate and credit default swap) markets. In an interest-free world, hedge funds would not be able to borrow at interest for the purpose of speculation. They would be compelled to invest in the real sector, rather than make loans, complete with income and capital guarantees. The size of their investments would be limited to their capital base of about 2.5 per cent of the leverage they are currently able to gain by borrowing at interest. This would dramatically reduce the impact of their speculative activities on various economies. Greater systemic stability could be expected to result.

Heavy debt loads and crushing interest rates also contributed to the Great Depression of 1929-1939. The financial and economic crisis of 2007 was similarly caused in part by excessive leverage (debt). In the wake of the crisis, economic recovery is stymied by the need to divert funds from spending in the real sector towards the repayment of debt. In the series of crises since the Great Depression, each crisis has been more severe than the one that preceded it. A measure of the extent of waste caused by interest-based lending can be found in 
the total amount of interest paid to lenders as a proportion of GDP. This ranges between 5 to 10 per cent of GDP. The total amount of interest paid in a year to all creditors is a measure of an economy's inefficiency. It is clear that financing by way of lending at interest is neither morally defensible, nor economically viable. In an interest-free economy, the money currently paid to lenders in the form of interest would flow to workers in the form of wages, corporations in the form of profits, and property owners in the form of rents. In other words, in an interest-free economy, real GDP can be expected to rise by the amount of interest currently paid to lenders, conservatively estimated at 8 per cent of GDP. ${ }^{16}$

It took several centuries for the harmful effects of interest-based financing to show themselves. They have appeared in the massive indebtedness of nations, businesses and individuals, as well as in dramatically distorted distribution of wealth. It is only a matter of time that unsustainable levels of debt will make it necessary to shift to another - Islamic - mode of financing, one that is free of the harmful effects of interest-based lending: risk sharing. One question is whether this shift will take place on a pro-active basis, or merely in response to another crisis, in all likelihood bigger than the most recent crisis.

\section{Ethics and the Law}

Every society endorses and upholds a set of values. These values comprise its "worldview." A worldview reflects a given society's understanding of itself and its place in the world. It also reflects its aspirations and specifies what the society looks up to and what it looks down upon. It comprises the community's beliefs, customs, laws, principles and divine imperatives it upholds and practices. The value system of a given community both mirrors and shapes its way of life. Adherence to shared values maintains social unity and cohesion. The most important ethical imperatives of a given community are embodied in its laws, which specify what is permitted and what is not. Laws make it clear what expectations the community has of its members, as well as the expectations members can have of one another. In societies with a heritage of divine revelation, ethical principles, and a significant number of its laws are derived to a greater or lesser degree from revealed sources of guidance.

The fundamental law of a modern nation is its constitution. While laws limit freedoms, they need to be designed in such a way as to allow each individual to realise his or her potential, without limiting the ability of others to realise theirs. The rule of law helps to bring out "the best in people and to restrain the worst," as individuals may follow their desires rather than act in their own best interests. The rule of law helps to ensure that collective existence will take place in a way that can be described as civilised. In this sense, the law has a fundamentally civilising role. It specifies what may and what may not be done, as well as the 
penalties meted out for transgressions. The "rule of law" is designed to overcome the arbitrariness implicit in the "rule of men."

Ethics comprise the rules or principles that guide action. Some actions or their consequences may not immediately affect a given person in any perceptible way, positive or negative. Other actions, however, may bring benefit or harm, either to the person responsible for it, to other persons or both. One example is the commission of a crime, which is likely to lend the perpetrator in jail. Another example is careless driving. This may result in harm to the driver, his or her passengers, or to others in case an accident should take place. By contrast, diligence and assiduousness bring rewards. Acting in accordance to good rules (principles) thus tends to bring success, while corrupt practices bring harm.

To the extent that the worldview of a community reflects truly ethical values it is likely to prosper. To the extent that the practices of a given society veer away from such values, it is likely to languish. Acting in accord with universal ethical principles contributes to the growth and blossoming of a community and its members. Departure from ethical principles brings decline and stagnation. It may also result in conflicts such as war, civil war or both. Numerous verses in the Qur'an relate how the decline of not a few communities was triggered by a disregard of ethical standards of conduct. ${ }^{17}$ To ensure that a given community is properly oriented (guided) requires on-going commitment to, and the observance of the ethical values that guide a given community.

Gaining income in the form of interest is fundamentally unethical because it enables lenders to gain a reward without giving up a palpable counter value in exchange, either in the form of work or in the form of a willingness to share risk. Justice requires that reward needs to be earned in order to be "deserved." The interest income of the lender, however, is not gained in exchange for any counter value. It is not paid in exchange for productivity. Neither is it paid, in the case of secured loans, in exchange for sharing risk. Interest income is paid to the lender solely in exchange for making the loan. In contrast to workers or investors, who earn wages or profits proportionate to the amount of work performed or risk taken, the interest paid to a lender is determined as a proportion of the loan he makes. The higher the amount of money he lends or the interest he charges, the higher is the amount of interest he gains.

\section{Reform}

Every reform initiative requires distinguishing between "what is" and what "ought to be." What "is" represents the actual. What "ought to be" is the ideal. Human achievement is represented by what is. Human potential is represented by what could be. The gap between the two is a measure of the success of an individual or society in living up to its own ideals. The magnitude of the gap reflects the 
degree to which a given individual or society falls short of the ideal. The smaller the gap, the better off is the society or individual. A major gap indicates that the society or individual is failing to live up to its own ideals. In such cases, reform is required. Social reform and education aim to narrow or close the gap between what is and what ought to be.

Contentment with the current state of affairs (status quo) does not help the cause of reform. ${ }^{18}$ If matters were always as they should be, there would not be any need for reform. A community that considers its current state of affairs as the best of all possible worlds has no incentive to take any action to improve the condition of its people. It will remain stagnant and may regress further. In so far as it is only human to err and to forget, the need for reform (islah) is everpresent. Where no desire for reform is present, error is likely to continue. Islam is not against change, as long as any proposed change is for the better. Indeed, the coming of Islam brought many changes for the better to the world.

Burying female infants was a common practice in Arabia before the coming of Islam, but was prohibited and discontinued. Slavery was acceptable at one time, but was later rejected and outlawed. This also applies to the practice of riba or interest. Thus, the laws or customs of a given community need not always be in harmony with the universal moral order espoused by Islam. In other words, there is no guarantee that, just because a given practice has become legal, it thereby also became ethical. ${ }^{19}$ The legalisation lending at interest is a case in point. ${ }^{20}$ Where laws fall short of expressing the principles of ethics, they need to be repealed or amended.

The majority of legal scholars have agreed that "syariah law proscribes the giving and taking of bank interest ...."21 Identifying and overcoming practices that are inconsistent with the teaching of Islam is a part of the responsibility of Muslims known as hisbah, ${ }^{22}$ "commanding what is good and prohibiting what is evil," (amr bi'l ma'rūf wa nahy 'an al-munkar). ${ }^{23}$

Reform begins, but does not end, with education. ${ }^{24}$ Change takes place through teaching, admonition, and finally legislation and enforcement. Practices that cause harm need to be discontinued or replaced by alternative practices that are in harmony with the ethical worldview of Islam. Reforms are sometimes triggered by crises. Crises bring the weaknesses of conventional practices to the fore by highlighting their consequences with a striking degree of clarity. The Great Depression resulted in many reforms being implemented to stabilise the financial and monetary system.

Before initiating change, it is necessary to develop consensus (ijma) that reform is required, the direction it needs to take, and how it will be carried out. Suitable institutes and think tanks need to be set up to spearhead reform. Academic publication as well as the media can assist in generating the required consensus 
and momentum for positive change. Since it was a moral transformation that facilitated the social acceptance of interest-based lending in the first place, it will likewise require a moral transformation to overcome it. What is required is a paradigm shift. To facilitate the implementation of the new paradigm, the "rules of the game" (laws) need to change. The roadmap is provided by Islamic finance. In order to facilitate the transition to interest-free financing, tax advantages should be extended to sellers willing to participate in interest-free finance.

Market forces can assist in reforming the financial system. For example, sellers should be legally permitted to sell their products - such as property, both residential and commercial - directly to buyers on credit, without utilising the costly services of financial intermediaries. In order to avoid riba, however, it is necessary to ensure that the credit price will be the same as the spot (cash) price. Currently the law in most nations does not permit this, except in the case of sales of furniture.

The problem with the current arrangements is that credit sales by furniture sellers, take place at credit prices that are higher, and in many cases much higher, than their spot prices. To be fair to customers and riba-free, it is necessary to ensure that the credit price be the same as the spot price. The law can ensure this, with stiff fines in place for violations to ensure compliance. Otherwise, riba will enter the transaction through the proverbial "back door." Sellers willing to accept instalment payments in interest-free credit sales will likely increase their sales, if for no other reason than that the prices at which they will be selling their products will be significantly lower (due to the absence of interest in the final price of the product). As the popular expression has it, "one bird in the hand is worth more than two in the bush."

Regulations in the sphere of civil transaction (mu'amalat) have a vast impact on how resources are allocated and how the fruits of economic activity will be distributed. Permitting housing developers to make credit sales directly to consumers, without interest, would dramatically reduce the cost of the houses and thereby increase the efficiency of transactions. The lower price of the houses would also increase the demand for houses, thereby significantly stimulating economic activity. The cost to consumers would be reduced by the amount currently paid to financial institutions in the form of interest. This would take place without reducing the profits of the producers, as these are already embedded in the cash (spot) price of a house. It would also put an end to the monopoly that financial institutions currently have on extending credit.

\section{Conclusions and Recommendations}

In order to restore finance to its ethical foundations, reform needs to take place both in the theory and in the practice of finance. This will require phasing out interest-based financing and carrying out all financing on the basis of risk sharing. 
The change to a system of financing by risk sharing may take place in one of two ways. Either through proactive measures, geared towards avoiding systemic instability, or by way of a crisis. In principle, it is preferable to avoid a crisis rather than react to it, as the former is likely to be less painful and traumatic. Bold steps are required, ones that address the root cause of instability, before a crisis itself forces change. The primary challenge is to transform the creditor/debtor relationship into a partnership relationship. This requires the adoption of risk sharing in preference to lending at interest.

Communism collapsed in part because of the injustice implied in its failure to reward and motivate people in proportion to their efforts. This was a direct consequence of severing the link between reward and productivity. Incentive to work was lacking. Disincentives for not working were likewise lacking. The link between effort and reward was severed by the prohibition of private enterprise and the right to own private property. Those more able or hardworking than others could not expect greater rewards. Those that did not exert themselves earned as much as those who did. Such a system of rewards can hardly promote efficiency or be in accord with justice. Like communism, interest-based financing severs the link between reward and performance, and thereby compromises not only the efficiency with which resources are allocated, but also the fairness with which the rewards of economic activity are distributed.

The task of reform is made more challenging by the fact that interest-based lending has been mixed up with, and become indistinguishable from "capitalism," or the pursuit of private profit through business enterprise. In competitive conditions, capitalism in principle is little different from trading (al bay'), which is explicitly permitted in the Qur'an. For capitalism to survive it needs to rid itself of interest-based financing. Justice demands that, except in cases of charity, gifts or inheritance, reward needs to depend on effort or, at the very least, be justified by sharing business risk.

It is hardly reasonable to expect meaningful change to take place without regulatory change. Regulations - in particular laws - impact relations between counterparties in important ways. They also affect how the fruits of economic activity will be distributed in a given society. Laws, in other words, determine to a significant degree how well or poorly justice will be served, if at all. In the absence of lending at interest, one can expect not only a more efficient allocation of resources, but also better compliance with the Shariah, not only in form, but more importantly in substance.

- The social costs of interest-based financing, such as unemployment, inflation, and reduced growth in the long term need to be highlighted.

- The benefits, personal as well as social, of ethical financing need to be emphasised. 
- Reform (islah) needs to be initiated and carried out through education and public awareness.

- Changes in the regulatory framework that will facilitate the adoption of risk sharing also need to be implemented.

\section{Notes}

* Abdul Karim Abdullah (Leslie Terebessy), Assistant Fellow at IAIS, earned his MA in political philosophy from the University of Toronto, Canada (1999) and a MEd (1986) from the University of Toronto's Ontario Institute for Studies in Education (OISE). A former lecturer, editor, writer and coordinator of the English programme at University Sains Islam Malaysia (USIM), his current projects involve research into the current financial crisis, critical thinking in Muslim societies, and Islamic Finance. He has edited Islamic Studies at World Institutions of Higher Learning (Kuala Lumpur: USIM 2004).

1. These perspectives are developed in some detail in the following papers: "The Role of Adjustable-rate Subprime Mortgages and Credit Default Swaps in the Global Financial Crisis," ICR, Vol. 1. No. 2, Dec. 2009; "Overcoming the Weaknesses in Sukuk: Towards Risk Sharing Instruments," ICR, Vol. 2. No. 4, July 2011; "Understanding the Causes of the Debt-Crisis: Interest-based lending," ICR, Vol. 3, Number 4, July 2012; "The Pitfalls of Riba or Interestbased Financing," ICR, Vol. 4, No. 1, Jan. 2013; "Risk Sharing, Transfer and Management," ICR, Vo. 4, No. 2, Apr. 2013; "Debt and Economic Activity," ICR, Vol. 4, No. 3, July 2013.

2. The maximum rate was 10 per cent and there was no difference between commercial and other loans. King Henry VIII, known for ostentatious living, became notorious for beheading two of his wives for being unable to bear a male heir. He dealt with his political opponents in the same way, in a wave of political executions from 1513 until his death in 1547 . He executed arbitrarily more English notables than any other king before or since. He broke with the Church in 1534, after it refused to grant him a divorce from his first wife. He subsequently declared himself as the Head of the Church of England. He debased the coinage in 1526 and 1539. He died in debt. He was an absolutist. Among his "reforms" was the destruction of the monasteries that were at the time the only means of support for the impoverished.

3. Lewis, Mervyn K., "The Cross and the Crescent: Comparing Islamic and Christian Attitude to Usury," pp. 1-23, Iqtisad, Vol. 1, No. 1, Center for Islamic Economic Studies and Development, April 1999, pp. 16-18.

4. Calvin permitted interest on commercial loans. The rationale applied in particular where a lender made a loan to a rich merchant. The lender had a right to a share of the rich man's profit. This however leaves the question of why a rich man would need to borrow in the first place, unanswered. Munro, John H., "Usury, Calvinism, and Credit in Protestant England: from the Sixteenth Century to the Industrial Revolution," Working paper 439, 2011, University of Toronto Department of Economics, p. 12, accessed online on 24 March 2013, <http:// www.economics.utoronto.ca/public/workingPapers/tecipa-439.pdf> 
5. Debasement of currency was another common method. "King Henry VIII engaged in an epic debasement of the currency, effectively defaulting on all the Crown's domestic debts. Moreover, he seized all the Catholic Church's vast lands. Such seizures [were] often accompanied by executions..." Rogoff, Kenneth S. \& Carmen M. Reinhart, This Time Is Different, Princeton University Press, 2009, pp. 87, 89.

6. Al-Jarhi, Dr. Mabid Ali, "Regaining the Ethical Standards of Islamic Finance," 2010, accessed online on 24 Oct. 2013, Association of Islamic Economics, p. 12. <http://www.assaif.org/content/download/8984/49463/file/Regaining\%20 the $\% 20$ Ethical $\% 20$ Standards $\% 20$ of $\% 20$ Islamic\%20Finance.pdf $>$

7. Zaman, Arshad and Asad Zaman "Interest and the Modern Economy," Islamic Economic Studies, Vol. 8, No. 2, April 2001, pp. 61-62, accessed online on 29 January 2013, <http:/www.irti.org/irj/go/km/docs/documents/ IDBDevelopments/Internet/English/IRTI/CM/downloads/IES_Articles>

8. Presley, John R., and John G. Sessions, "Islamic Economics: The Emergence of a New Paradigm," The Economic Journal, Vol. 104, No. 424, (May 1994), pp. 584-596, pp. 3-4, Blackwell Publishing, accessed online on 29 March 2013; $<$ http://www.jstor.org/stable/2234633>

9. Sami M. Abbasi, Kenneth W. Hollman, Joe H. Murrey, Jr., "Islamic Economics: Foundations and Practices", International Journal of Social Economics, Vol. 16, No. 5, (1989) pp. 5-17, p. 14; accessed online on 30 Mar. 13; <http://www. emeraldinsight.com.myaccess.library.utoronto.ca/journals.htm?issn=0306$8293 \&$ volume $=16 \&$ issue $=5 \&$ articleid $=846964 \&$ show $=$ pdf $\&$ PHPSESSID $=\mathrm{k} 80$ okat89nkq7pnu1rj5rct612>

10. Richards, Richard David, The early history of banking in England, P.A.M. Kelley, 1929, p. 19.

11. Government debt is paid off when the central bank buys government issued bonds, which is an equivalent to printing money, also known as quantitative easing. This way of reducing debt, also known as the "monetisation" of debt, however adds to inflation and erodes the purchasing power of currency. Some economists refer it to as a form of "default." Rogoff, Kenneth S. \& Carmen M. Reinhart, This Time Is Different, Princeton University Press, 2009, pp. 6-7.

12. High taxes are destructive of the community, as noted by Ibn Khaldun, among others. "Eventually the taxes will weigh heavily upon subjects and overburden them ... The assessments increase beyond the limits of equity ... Finally civilization is destroyed." Ibn Khaldun, quoted in Alfred Gierer, "Ibn Khaldun on Solidarity ("Asabiyah") - Modern Science on Cooperativeness and Empathy: a Comparison," Philosophia Naturalis 38, pp. 91-104 (2001), accessed online on 31 Jan 2013, <http://www.icts.res.in/media/uploads/Talk/ Document/ibn\%20 khaldun $\% 20-\% 20$ gierer.pdf>

13. Abbadi Suleiman, "Ibn Khaldun's contribution to the science of economics," pp. 41-48, Journal of Al-Azhar University-Gaza, 2004, Vol. 7, No. 1, p. 45, accessed online on 19 Jan. 2013; <http://www.alazhar.edu.ps/journal123/attachedFile. asp? seqq $1=565>$

14. "The top employees of the five largest investment banks divided a bonus pool of over \$36 billion in 2007.” Rogoff, Kenneth S. \& Carmen M. Reinhart, This Time Is Different, Princeton University Press, 2009, p. 210. 
15. One can observe a surplus of luxury accommodation and office space side by side with overcrowded housing areas in almost any major metropolitan centre.

16. In the US, for example, "Personal interest income as a share of GDP has grown steadily for several decades. The share grew from 8.2 percent of GDP in 1978 to 11.4 percent in 1988...” 2045 BEA Regional Projections, Bureau of Economic Analysis, accessed online on 31 December 2013; <http://www.ctre.iastate.edu/ research/bts_wb/cd-rom/employment/bea.htm>

17. Qur'an, 6:6, 7:4, 8:54, 10:13, 17:17, 18:59, 19:74, 19:98, 20:128, 21:9, 21:11, 22:45, 26:139, 28:58, 28:59, 29:31, 32:26, 44:37, 46:35, 47:8, 47:13, 53:53, 69:9.

18. Zaman, Arshad and Asad Zaman, "Interest and the Modern Economy," Islamic Economic Studies, Vol. 8, No. 2, April 2001, pp. 66, accessed online on 29 January 2013,<http://www.irti.org/irj/go/km/docs/documents/IDBDevelopments/ Internet/English/IRTI/CM/downloads/IES_Articles>

19. Al-Jarhi, Dr Mabid Ali, "Regaining the Ethical Standards of Islamic Finance," 2010, accessed online on 24 Oct. 2013, Association of Islamic Economics, p. 6. $<$ http://www.assaif.org/content/download/8984/49463/file/Regaining\%20 the $\% 20$ Ethical $\% 20$ Standards $\% 20$ of $\% 20$ Islamic\%20Finance.pdf $>$

20. Muslim scholars agree that all forms of interest, small or large, constitute forbidden ribā. El-Husseini, Ibrahim Ali, "Islamic Financial Principles and their applications in project financing," Massachusetts Institute of Technology, May 1988, p. 55, accessed online on 30 March 2013; <http://dspace.mit.edu/ bitstream/handle/1721.1/44667/19461810.pdf?sequence=1>

21. Kamali, Mohammad Hashim, "Debt management with a conscience," New Straits Times, Kuala Lumpur, 8 July 2009, p. 16.

22. Kamali, Mohammad Hashim, Freedom, Equality and Justice in Islam, Ilmiah Publishers, 2002, p. 110.

23. Chapra, M. Umer "Ibn Khaldun's theory of development: Does it help explain the low performance of the present-day Muslim world?" The Journal of Socio-Economics, 37 (2008) 836-863, p. 840, accessed online on 5 April $2013,<$ http://journals2.scholarsportal.info.myaccess.library.utoronto.ca/ tmp/2418629081465730411.pdf>

24. Kamali, Mohammad Hashim, "Source, Nature and Objectives of Shariah," Islamic Quarterly, Vol. 33, 1989, pp. 215-234, p. 225, accessed online on 29 Oct. 2013; <http://www.hashimkamali.com/index.php/publications/item/113sources-nature-and-objectives-of-the-sharicah> 